\title{
圧電素子誘起圧カ波法の改良およびパルス静電応カ法との比較
}

\author{
学生員 佐藤 勇樹（武蔵工業大学） \\ 正員田中康寛（武蔵工業大学） \\ 正員高田達雄（武蔵工業大学）
}

\section{Improvement of Piezo-electrically Induced PWP Method and Its Comparison with PEA Method}

\author{
Yuki Satoh, Student Member, Yasuhiro Tanaka, Member, Tatsuo Takada, Member
}

(Musashi Institute of Technology)

The pulsed electroacoustic (PEA) method and the piezo-electrically induced pressure wave propagation (PIPWP) method are compared. While the PEA method has been widely used as a measurement technique to observe space charge distributions in solid dielectric materials, the PIPWP method has not been widely used because of its relatively lower spatial resolution as compared to that of the PEA method. Therefore, in this research, an attempt has been made to improve the resolution of the PIPWP method. In this paper, principles of the generation and the detection of pressure waves in both PEA and PIPWP methods are summarized. Furthermore, the two methods are compared through observations of the generation, drift and trapping of carriers in an organic photoconductor (OPC)

キーワード： 空間電荷、压電素子誘起圧力波法、パルス静電忘力法、有機感光体

\section{1.はじめに}

現在、代表的な固体誘電・絶縁材料中の空䦎電荷 分布測定法としては、パルス静電忘力 $(\mathrm{PEA})$ 法 $^{(1,2)}$ 、 レーザー誘起圧力波(LIPP) 法 ${ }^{(3)}$ 、圧電素子誘起圧力 波法 (Piezo-electrically induced pressure wave propagation, PIPWP 法と格す) ${ }^{(4)}$ 等が举げられる。 しかし、実祭には主にPEA 法とLIPP法が用いられ ており、PIPWP 法法あまり用いられていない。その 理由として、従来は厚い圧電素子に高電圧方形波パ ルスを印加することにより圧力波パルスを発生さ せていたが、この方法では十分に幅の狭い压力波を 発生させることが困難であり、满足な位置分解能を 得られなかったことが挙げられる。そこで我々は压 力波法に掠ける压力波の発生手法の改良を行うこ とにより、電荷分布測定に扔ける位置分解能や信号 出力が、PEA法によるものとほぼ同等の性能を有す る測定装置を開発した。本報告では、PEA 法上 PIPWP 法に打厌力波の発生や検出等の原理に ついてまとめ、比較を行った。また、測定例として 試料に積留型感光体を用い、それぞれの手法で有機 感光体 (Organic Photoconductor, 以下 OPC 上略寸) 内の電荷举動観察 ${ }^{(5)} の$ 結果を示し、比較と娭討を行 った。

\section{PEA 法と改良PIPWP 法の測定原理の比較}

従来のPIPWP 法 ${ }^{(4)}$ から改良した点は、パルス圧力 波の発生方法である。従来は厚さが数 $\mathrm{mm}$ の圧電素 子(ニオブ酸りチウム: $\mathrm{LiNbO}_{3}$ ) にパルス幅が $13 \mathrm{~ns}$ 、 波高值が数 $\mathrm{kV}$ 程度の高電圧パルスを印加し、パル ス圧力波を発生させていた ${ }^{(4)}$ 吕、今回の手法では厚 さが $d=9 \mu \mathrm{m}$ のポリフッ化ビニリデン (PVDF) に波 高值 $v_{s}=600 \mathrm{~V}$ のステップ状電在を印加してパルス 圧力波を発生させた。このことを踏まえて、表 1 に PEA 法とPIPWP 法の原理図と压力波の発生と検出 におけるモデルと式を示す。PEA法は、表 1 の左の 欄（原理図）に示すように、内部に電荷 $\rho(\tau)$ が蓄 積した試料にパルス電在 $e_{p}(t)$ を印加することで 試料中の蓄積電荷に静電応力を発生させ、それによ る圧力波 $p(t)$ を圧電素子で検出し電压信号 $v(t)$ に変換し、試料内の電荷分布を測定する方法である。 但し、 $\rho\left(\tau=x / u_{s}\right)$ は位固 $x$ の関数を試料中の音速 $u_{s}$ で除し、時閒の関数に置き換えたものである。また PIPWP 法は、同表の右の欄（原理図）に示すように 内部に電荷 $\rho(\tau)$ が存在する試料にパルス圧力波 $p(t)$ を伝搬させ、この際、外部回路に流れる変位電 流 $i(t)$ を測定することにより、試料の厚さ方向の 電荷分布を求める方法である。 
PEA 法に招いて、表 1 中(1)式で発生する圧力波 $p(t)$ は、印加するパルス電界 $e_{p}(t)$ の幅 $\Delta t$ に依存す る。但し、(1)式で、 $Z_{s}$ は試料、 $Z_{A l}$ はアルミニウム 電極の音響インピーダンスである。また、表 1 中(2) 式より、検出信号 $v(t)$ は圧電素子の圧電定数 $h(\tau)$ の幅 $\Delta \tau$ に依存する。但し、(2)式で、 $u_{p}$ は圧電素子 中の音速、 $S$ は電極面積、 $\mathrm{C}_{p}$ は圧電素子の静電容量、 $Z_{p}$ は圧電素子の音響インピーダンスである。 $p(t)$ が圧電菜子を通過する時間 $d / u_{p}$ に等しい。従っ て、PEA 法の位置分解能は $\Delta t$ と $d$ に依存している ことがわかる。今回行う実験では、 $\Delta t=5 \mathrm{~ns} 、 d=9 \mu \mathrm{m}$ 、 $u_{p}=2260 \mathrm{~m} / \mathrm{s}$ である。従って $\Delta \tau$ は約 $4 \mathrm{~ns}$ とな。 方形波と方形波が䁷み込まれたとき、出力は台形波 となるが、この半值幅は幅の長い方のパルス幅と一 致する。このように、出力信号の半值幅は、盢み込

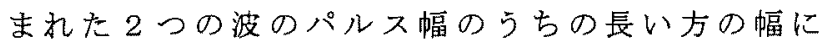

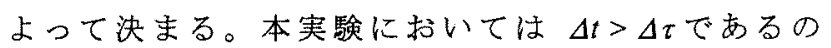

で、試料中の音速 $u_{\mathrm{s}}=2000 \mathrm{~m} / \mathrm{s}$ とすると、位圈分解 能は約 $10 \mu \mathrm{m}\left(=\Delta t \times u_{\mathrm{s}}\right)$ となる。

一方、PIPWP 法において、圧電素子にステップ状 の電界 $e_{p}(t)$ を印加することで発生する圧力波 $p(t)$ は表1中の(3)式に示す畳み込み積分で表せる。但し、 表 1 中 $(3)$ 式で $g(\tau)$ は圧電素子の電歪定数である。こ の時発生する圧力波形は圧電素子の厚さ $d$ と印加 するステップ電圧波形の立ち上がり時間 $\Delta t_{r}$ に依存 する。この $p(t)$ が電荷 $\rho(\tau)$ の蓄積した試料中を伝 搬することにより、試料を含む閉回路に変位電流が 流れ、電流信号 $i(t)$ が得られる。この $i(t)$ は表 1 中 $(4)$ 式に示す盢み込み積分で表せる。但し、E，性料の ヤング率、l$l$ は試料の厚さである。よって位置分解 能は $d$ と $\Delta t_{r}$ に依存する。今回の寒験では $\Delta t_{r}=1 \mathrm{~ns} 、$ $d=9 \mu \mathrm{m} 、 u_{p}=2260 \mathrm{~m} / \mathrm{s}$ である従って $\Delta \tau$ は約 $4 \mathrm{~ns}$ であり、 $\Delta t_{r}<\Delta \tau$ となり、 $u_{\mathrm{s}}=2000 \mathrm{~m} / \mathrm{s}$ とすると、 位置分解能は約 $8 \mu \mathrm{m}\left(=\Delta \tau \times u_{\mathrm{s}}\right)$ となる。

\section{表 1.PEA 法と改良されたPIPWP 法の比較}

Table. 1. Comparison between the PEA method and the improved PIPWP method.

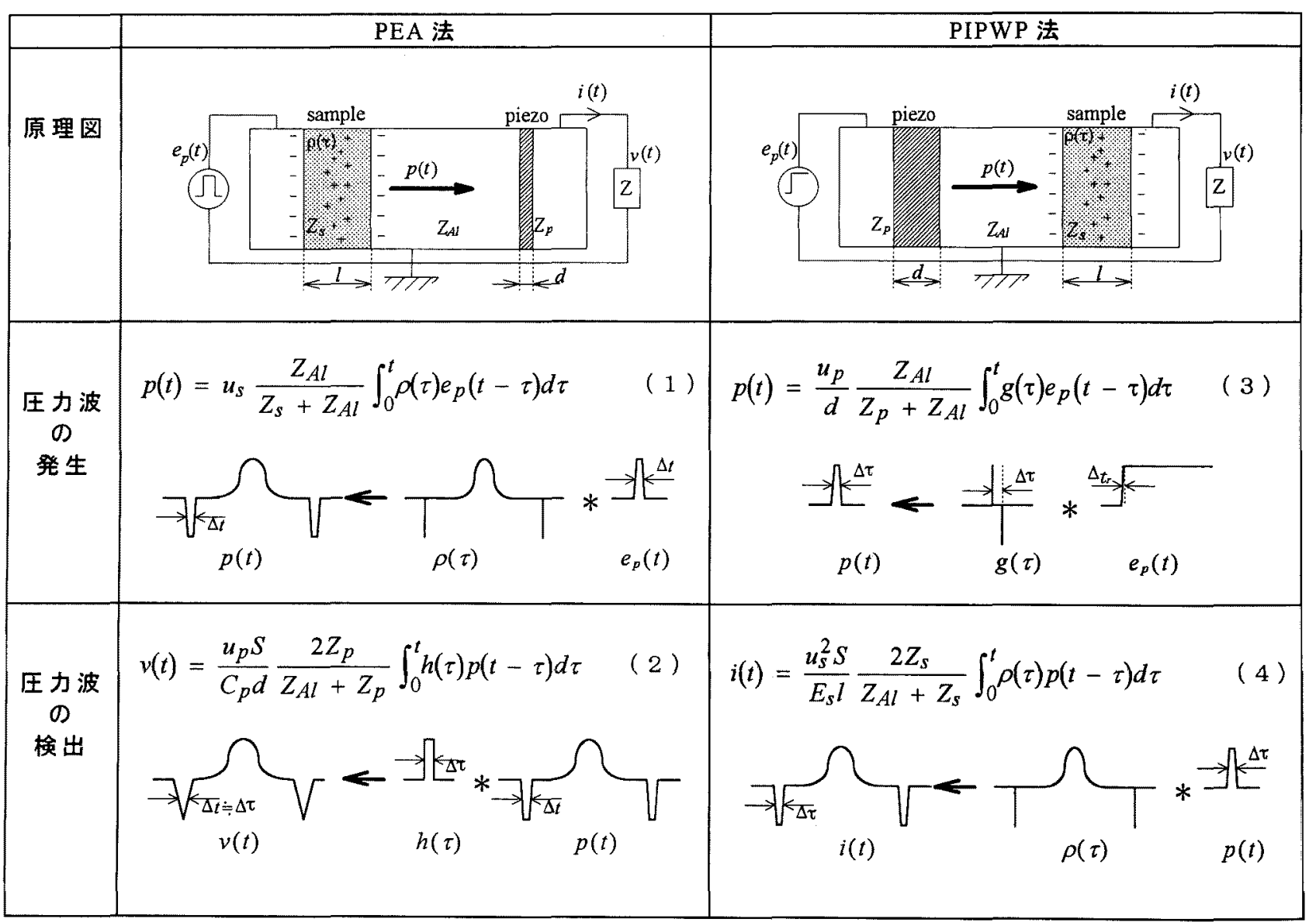

*印は畕み込み樌分を表す。 
今回の PIPWP 法の改良によって、王電素子に印加 される電界 $e_{p}\left(=v_{s} / d\right)$ が従来の数十倍になったこと から、数 ns 幅のパルス圧力波が高出力で得られ、 位置分解能のみならず、測定感度も飛躍的に向上し ている。

原理的には両手法は類似しているが、以下の相違 点がある。(1) PEA 法と比較してPIPWP 法は試料に 電気的な刺激を与えることなく測定できる。(2) PIPWP 法では試料が信号検出回路の一部となって いるので、試料に直流高電圧源が接続されている場 合には、この電圧源はコンデンサを通して増幅器に 接続されていることになり、增幅器を壊しやすい。

\section{3 . 測定装置}

PEA法打よびPIPWP法の測定装置をそれぞれ図1、 2 示市。

図1のPEA法の装置では、電極 I とアルミニウム蒸 着電極の間に試料を挟み、試料には土 $2 \mathrm{kV}$ の直流電 圧を印加できる。今回の赛験では、アルミニウム蒸 着電極に $600 \mathrm{~V}, 5 \mathrm{~ns}$ のパルス電压を印加して圧力 波を発生させる。発生した圧力波は電極Iを伝搬し、 $\operatorname{PVDF}(9 \mu \mathrm{m})$ に到達する。圧力波は電圧信号に変換 され 2 つ增幅器 (Tronteck W500, Hewlett Packard HP8447F) で増幅後、ディジタイジングオシロスコ 一プ (LeCroy 9350A) で観測される。

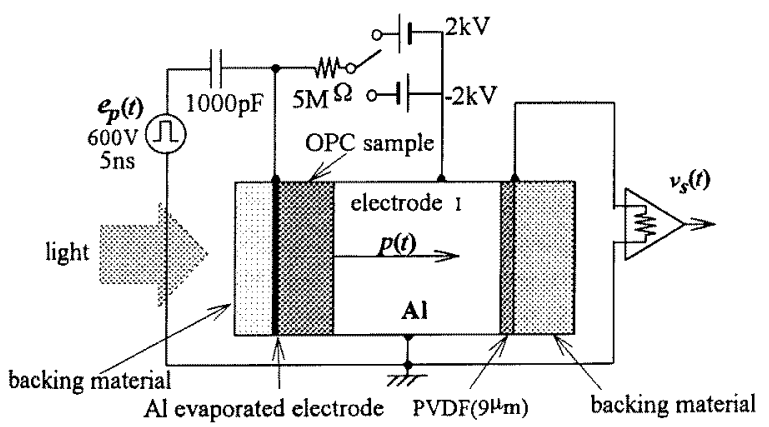

图 1。PEA 法の測定装置

Fig.1. Schematic diagram of the PEA method.

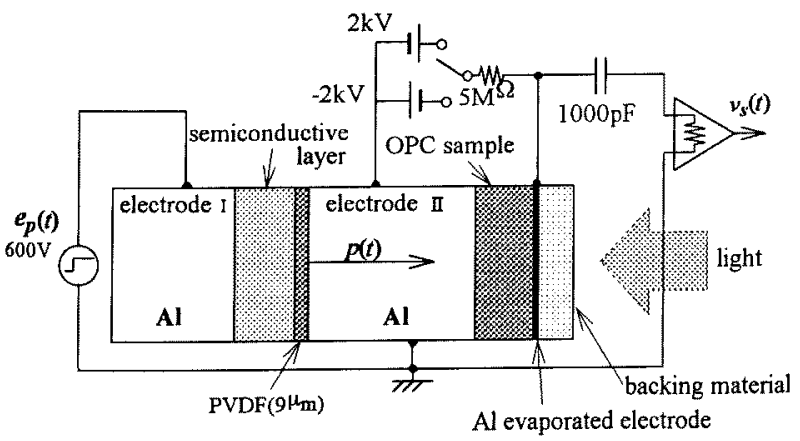

图 2.PIPWP 法の測定装置

Fig. 2. Schematic diagram of the PIPWP method.
一方、図2に示したPIPWP法の装固では、電極I と 電極】の間に半導電層と PVDF $(9 \mu \mathrm{m})$ を挟み、 PVDFに $600 \mathrm{~V}$ のステップ状の電圧を印加して圧 力波を発生させる。ここで発生した压力波はアルミ 二ウム電極を経て試料に伝搬する。出力電流信号は $1000 \mathrm{pF}$ 結合コンデンサを介して、增幅器 (Hewlett Packard HP8447F) で増幅後、デイジタイジ ングオシロスコープ (LeCroy 9350A) で観測される。

試料上電圧印加部の電極との音響整合をとるた めポリエチレンテレフタレート (PET)フィルムにア ルミニウムを蒸着したものを電極として用いてい る。なお、このアルミニウム蒸着電極は半透明で、 試料に光を照射する際に十分に白色光を透過でき るものである。

\section{4.試料およひ実験結果}

\section{$\langle 4-1\rangle$ 試料構成}

OPC 試料には積層型感光体を用いた。その構成 を図 3 に示す。今回用いた積層型感光体では、電 界が印加された状態で光を照射するとキャりア発 生層 CGL (Carrier Generation Layer) 中でキャリア 対が生成され、ホールのみがキャリア輸送層 CTL (Carrier Transport Layer) 中を電界方向に沿って移 動し、正孔捕獲層 HTL(Hole Trap Layer) で捕獲さ れる。なお、今回の実験では、電荷の注入を防ぐ

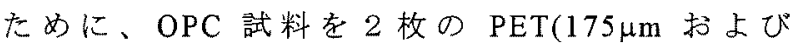
$50 \mu \mathrm{m})$ で挟んで実験に供した。HTLの厚さは $1 \mu \mathrm{m}$ 以下で、ポリエチレングリコールが用いられてい る。CTLの厚さは $140 \mu \mathrm{m}$ で、バインダのポリカー ボネートにはホール輸送材としてスチルベン系ド ナーが分子分散されている。CGLの厚さは $0.1 \mu \mathrm{m}$ でトリスアゾ顔料を用いたものである。

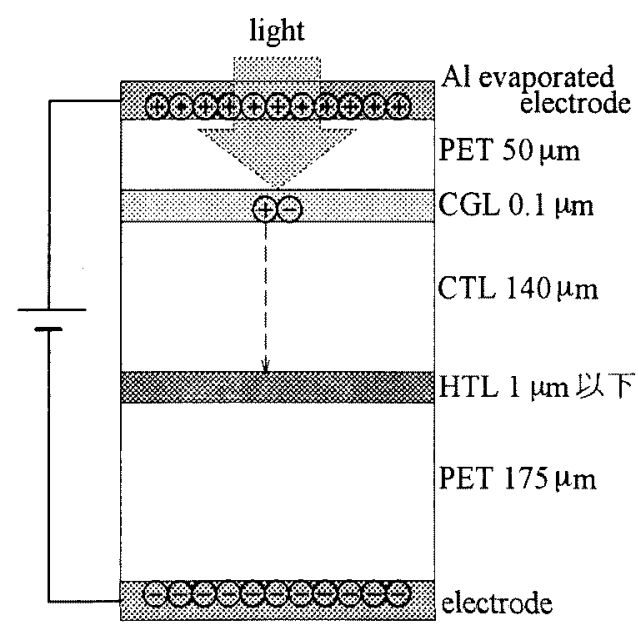

図 3. OPC 試料構成

Fig. 3. Structure of OPC. 


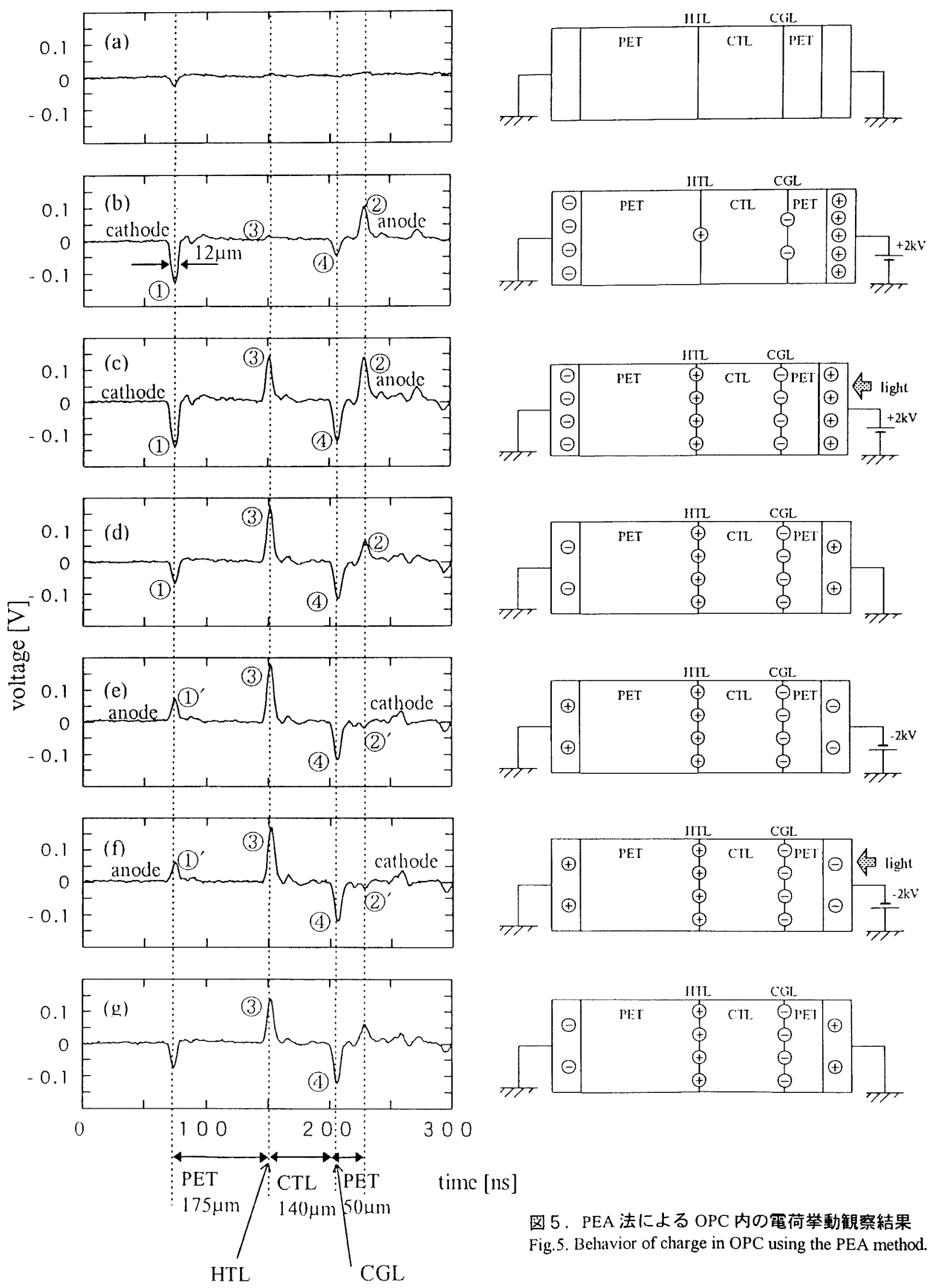




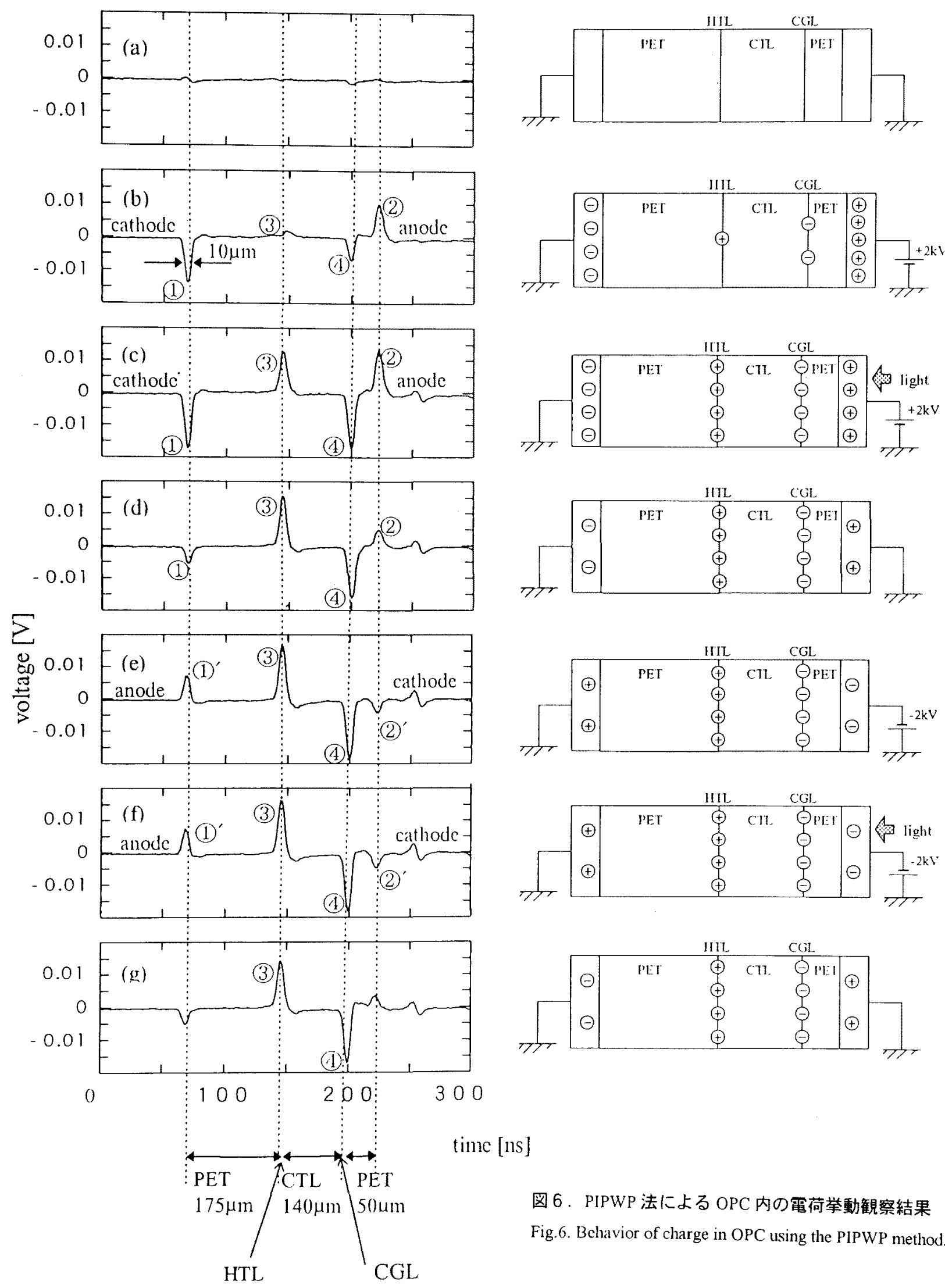




\section{$\langle 4-2\rangle$ 測定条件}

試料への直流電圧の印加および光照射の条件を 図 4 に示す。試料に印加する電圧は土2kVで、それ ぞれの極性で電圧印加中に白色光を照射した。

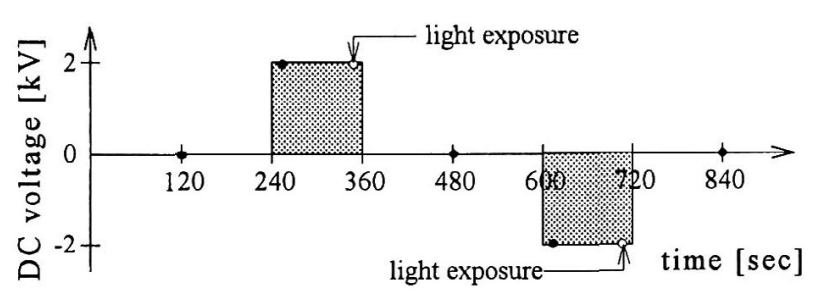

図 4. 測定条件

Fig.4.Measuring

\section{〈4-3〉測定結果及び考察}

PEA 法による積層型感光体内の電荷挙動観察の 結果を図 5 に、PIPWP法による結果を図 6 に示す。

まず、両図中 (a)においては試料の初期状態を示 す。電圧印加および光照射していない状態では、試 料中に電荷は観測されていない。次に試料に $+2 \mathrm{kV}$ の直流電圧を印加した状態を両図中(b)に示す。電 極とPETの界面に誘導電荷 (1)(2)が現われている。電 圧を印加したままの状態で光照射を行うと、両図中 (c)に示亦ように、CGL 中で正負キャリア対が生成 され、外部電界方向にホール(正電荷) (3)のみが移 動していることが観察できた。なお、両図中(b)に おいても HTLおよび CGL 中に、それぞれわずかな 正および負電荷 (3)(4)が観測されているが、これは再 結合を兔れたキャリア対が存在したため、電圧印加 により正電荷が移動し観測されたものと思われる。 このあと光を遮断し、電極の両端を短絡した状態を 両図中(d)に示す。この時ホール (3) HTLにトラッ プされており、CGL 内には負の電荷(4)が残ってい る様子が観測されている。次に印加電压の極性を反 転させて $-2 \mathrm{kV}$ を印加した結果を両図中(e)に示す。 印加電圧の反転とともに電極と PET の界面に誘導 されている電荷の極性 (1)'(2)'も反転していること がわかる。しかし、OPC 試料内での電荷 (3) (4)の移 動は見られなかった。さらに光照射を行ったが、特 に変化は現れなかった。最後に再び光を遮断し、電 極の両端を短絡したが、両図中(d) と同様にホール (3) H HTL 中にトラップされたままであった。

図 5、6で明らかなように、これらの結果はどち らの測定方法においても同じょうに測定できてい ることがわかる。PIPWP法およびPEA 法における 位置分解能を、両図中 (b)の表面電荷 (1)のピークの 半值幅から評価すると、それぞれ $10 \mu \mathrm{m}$ おるび $12 \mu \mathrm{m}$ 程度である。PIPWP 法およびPEA法における 理論的な位置分解能は、前述したように、試料中の 音速を $2000 \mathrm{~m} / \mathrm{s}$ とした場合、それぞれ $8 \mu \mathrm{m}$ および
$10 \mu \mathrm{m}$ 程度であるので、ほぼ理論通りの位置分解能 が得られていると考えられる。また、PEA 法により 得られた出力電圧值は PIPWP 法で得られたものの 10 倍程度になっているが、PEA 法では装置の都合 上、 $30 \mathrm{~dB}$ の増幅器を一つ多く使っており、信号レ ベル自体はほぼ同等程度であると思われる。

\section{5. まとめ}

従来の、厚い圧電素子に幅の狭い高電圧パルスを 印加する手法から、薄い圧電素子にステップ状の電 圧を印加することにより、PIPWP 法を改良した。こ の改良により、従来の手法に比べて高感度の測定が 可能になった。また、この方法を積層型感光体内の 電荷挙動観察に適用し PEA 法と測定結果を比較し た。PEA 法では試料に5ns のパルス電圧を印加し て、厚さ $9 \mu \mathrm{m}$ の圧電素子(PVDF)で検出を行い、 PIPWP 法では、厚さ $9 \mu \mathrm{m}$ の圧電素子(PVDF) に立 ち上がり約 $\operatorname{lns}$ のステップ状の電圧を印加し測定を 行った。測定結果から、どちらの測定方法を用いて も $10 \sim 12 \mu \mathrm{m}$ 程度の位置分解能で空間電荷分布が 測定でき、両者ともほぼ同性能の測定装置であるこ とがわかった。

最後に、試料を提供していただきました(株) リコ 一の酒井捷夫、増田潔両氏に感謝いたします。なお、 本研究の一部は文部省科学研究費補助金 (No.08045043)を得て行われた。

(平成 8 年 2 月 26 日受付、平成 8 年 10 月 7 日再受付)

文献

(1) Y.Li, M.Yasuda and T.Takada, IEEE Trans. DEI, $1,188 \sim 195(1994-2)$

(2) T.Maeno, T.Futami, H.Kushibe, T.Takada and C.M.Cooke, IEEE Trans. Elect. Insul., 23, 433 D.439 (1988-3)

(3) J.Lewiner, IEEE Trans. Electr. Insul., 22, 351 360, (1986)

(4) T.Takada,K.Soda and K.Gotoh, J.J.A.P.,29,1198 1202(1990)

(5) A.Tanaka,M.Maeda and T.Tanaka,IEEE Trans. Elect. Insul., 27 440 444 (1992)

(6) H.Sumino, Y.Tanaka and T.Takada, Proc.ISE 8,236 〜 241(1994)

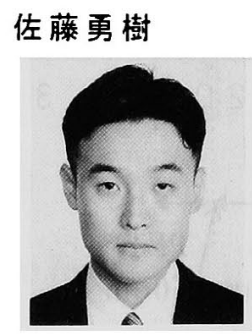

(学生員) 1973 年 2 月 3 日生ま れ。武蔵工業大学大学院生産機 械工学専攻修士課程在学中。主 として、固体誘電体内部の電荷 分布測定法に関する研究に従 事。

田中康寛 (正員) (電学論 A, 116 巻 8 号, p.689 参照) 高田達雄 (正員) (電学論 A, 116 巻 8 号, p.689 参照) 